\title{
Analysis of Factors that Affect the Inequality of Income Distribution of Regencies in Bali Province
}

\author{
I Gede Agus Astapa ${ }^{1}$ I Ketut Putu Suniantara ${ }^{2}$ and I Putu Winada Gautama ${ }^{3}$ \\ ${ }^{1-2}$ Department of Information Systems \\ ${ }^{1-2}$ Institute of Technology and Business STIKOM Bali \\ ${ }^{3}$ Department of Mathematics, Faculty of Mathematics and Sciences, Udayana University
}

Denpasar, Bali

Indonesia

\begin{abstract}
The purpose of economic development is essential to improve the welfare of society. Improving public welfare must be balanced with an increase in inequitable economic growth. There are 8 regencies and a city in Bali to be a concern in this study. One measure of the success of economic development is the level of inequality in income distribution. The purpose of this study is to analyze the factors that influence the inequality of income distribution between city/regencies in Bali. The type of data used is secondary data with the type of panel data which is a combination of time-series data from 2012-2017 with cross-section data from 8 regencies and a city in Bali. Data is processed by panel data analysis with fixed effect model regression. The variables used in this study are dependent and independent variables. The dependent variable is the level of inequality in income distribution as measured by the Gini Index, while the independent variables are regional government expenditures (average expenditure per capita), regional minimum wages, population, and the contribution of the tourism sector (travel agents, restaurants). Panel data analysis in this study produced the best model, namely Random Effect Model. The independent variable "Regional Expenditures" negatively affects the inequality of income distribution in Bali in 2012-2017.
\end{abstract}

Key Words: Cross-Section Data, Fixed Effect Model, Income Inequality, Panel Data Analysis, Regional Expenditures.

\section{INTRODUCTION}

Improving the welfare of society is essentially the goal of economic development. It is not easy to achieve this goal. In order to improve the welfare of the community, it is necessary to increase the equitable economic growth of income distribution [1]. Spread 8 regencies and a city in Bali which became the center of attention in this study. One measure of the success of economic development is the level of inequality in income distribution [2]. Various factors can influence the inequality of income distribution, both economic and non-economic factors [3]. The purpose of this study is to analyze the factors that influence the inequality of income distribution between city/regencies in Bali Province. The data used in this study is secondary data with the type of panel data which is a combination of time series data from 2012-2017 with cross-section data from 8 regencies and a city in Bali [4]. The main data source that will be used in this study is the Bali Provincial Statistics Agency. Data is processed by panel data analysis. The variables used in this study are dependent and independent variables. The dependent variable is the level of inequality in income distribution as measured by the Gini Index, while the independent variables are regional government expenditures (average per capita expenditure), regional minimum wages, population, and tourism sector contributions (travel agents, restaurants, and restaurants). This research is expected to be able to provide information about the factors that influence the level of inequality in income distribution between city/regenciesin Bali Province so that it can be used as a reference for policy making for local governments.

\section{MODEL PAPER}

The data used in this study is secondary data with the type of data panel which is a combination of time series data from 20122017 with cross-section data from 8 regencies and a city in Bali. The main data source that will be used in this study is the Central Statistics Agency of the Province of Bali. The data needed includes: 
International Journal of Advances in Scientific Research and Engineering (ijasre), Vol 5 (7), July-2019

1. Gini Index from 8 regencies and Denpasar city in Bali for the period of 2012-2017.

2. Regional Government Expenditures (average per capita expenditure) in each regency and Denpasar City in Bali for the period 2012-2017.

3. Regional minimum wages in each regency and Denpasar City in Bali for the period 2012-2017.

4. Population in each regency and Denpasar city in Bali for the period 2012-2017.

5. The contribution of the tourism sector (number of travel agents and restaurants) from the regencies and Denpasar city for the period 2012-2017.

This study uses an econometric model. Based on the frame of mind described earlier and to identify factors that influence income inequality between city/regencies in Bali Province over a period of 6 years, it can be explained the relationship of dependent and independent variables in a functional relationship as follows

$$
Y_{i t}=f\left(X_{1}, X_{2}, X_{3}, X_{4}\right)
$$

Equation (1) are arranged following the model form of Akai and Sakata [5], where (1) is transformed into a semi-log form. Variables that are transformed into the form of natural logics are regional government expenditures, regional minimum wages, and population. This is based on refining data where the data is on Regional Government Expenditures (average per capita), regional minimum wages, and population in the form of thousands while the Gini index and the contribution of the tourism sector in the number and have a number difference. Based on these considerations, the following models will be used in the study:

$$
Y_{i t}=\beta_{0}+\beta_{1} \ln X_{1 i t}+\beta_{2} \ln X_{2 i t}+\beta_{3} \ln X_{3 i t}+\beta_{4} \ln X_{4 i t}+u_{i t}
$$

Where

$Y=$ income inequality between city/regencies (Gini Index)

$X_{1}=$ regional government expenditure (million rupiah)

$X_{2}=$ regional minimum wage (million rupiah)

$X_{3}=$ population (thousand people)

$X_{4}=$ tourism sector contribution

$\beta_{0}=$ constants

$\beta_{1}, \beta_{2}, \beta_{3}, \beta_{4}=$ regression coefficients

$i=$ city/regencies $(1,2,3,4,5,6,7,8)$

$t=\mathrm{year}(2012-2017)$

$u_{i t}=$ error component at time $t$ and city/regencies $i$

\section{RESULTS AND DISCUSSION}

The size of the distribution inequality can be seen from the Gini index. This coefficient is an indicator that shows the level of overall income inequality. This measure was first developed by the statistician and Italian sociologist named Corrado Gini in 1912. The Gini coefficient has a range of values between 0 and 1. Perfect income equalization is indicated by a zero value. The smaller the value of the Gini coefficient, the more evenly the distribution of income. On the other hand, the more the Gini coefficient or the closer to one, the more unequal the distribution of income. Criteria for income inequality based on this coefficient, namely:
a) $\quad$ 0.71-1.00 shows very high inequality;
b) $\quad 0.50-0.70$ shows high / sharp inequality;
c) $0.36-0.39$ shows moderate inequality;
d) $\quad 0.20-0.35$ shows low inequality 
International Journal of Advances in Scientific Research and Engineering (ijasre), Vol 5 (7), July-2019

Table1. Gini Coefficient by Regencies / City in Bali

\begin{tabular}{|l|l|l|l|l|l|l|}
\hline \multirow{2}{*}{ Regency / City } & \multicolumn{7}{|c|}{ Gini Coefficient } \\
\cline { 2 - 7 } & 2012 & 2013 & 2014 & 2015 & 2016 & 2017 \\
\hline Jembrana Regency & 0.37 & 0.37 & 0.39 & 0.31 & 0.36 & 0.32 \\
\hline Tabanan Regency & 0.35 & 0.39 & 0.40 & 0.36 & 0.34 & 0.31 \\
\hline Badung Regency & 0.33 & 0.35 & 0.34 & 0.31 & 0.32 & 0.32 \\
\hline Gianyar Regency & 0.34 & 0.33 & 0.38 & 0.32 & 0.30 & 0.27 \\
\hline Klungkung Regency & 0.35 & 0.36 & 0.35 & 0.37 & 0.36 & 0.37 \\
\hline Bangli Regency & 0.31 & 0.31 & 0.33 & 0.38 & 0.35 & 0.30 \\
\hline Karangasem Regency & 0.29 & 0.33 & 0.34 & 0.31 & 0.29 & 0.32 \\
\hline Buleleng Regency & 0.33 & 0.38 & 0.39 & 0.34 & 0.34 & 0.31 \\
\hline Denpasar City & 0.42 & 0.36 & 0.38 & 0.36 & 0.33 & 0.34 \\
\hline
\end{tabular}

Source: BPS Bali 2017

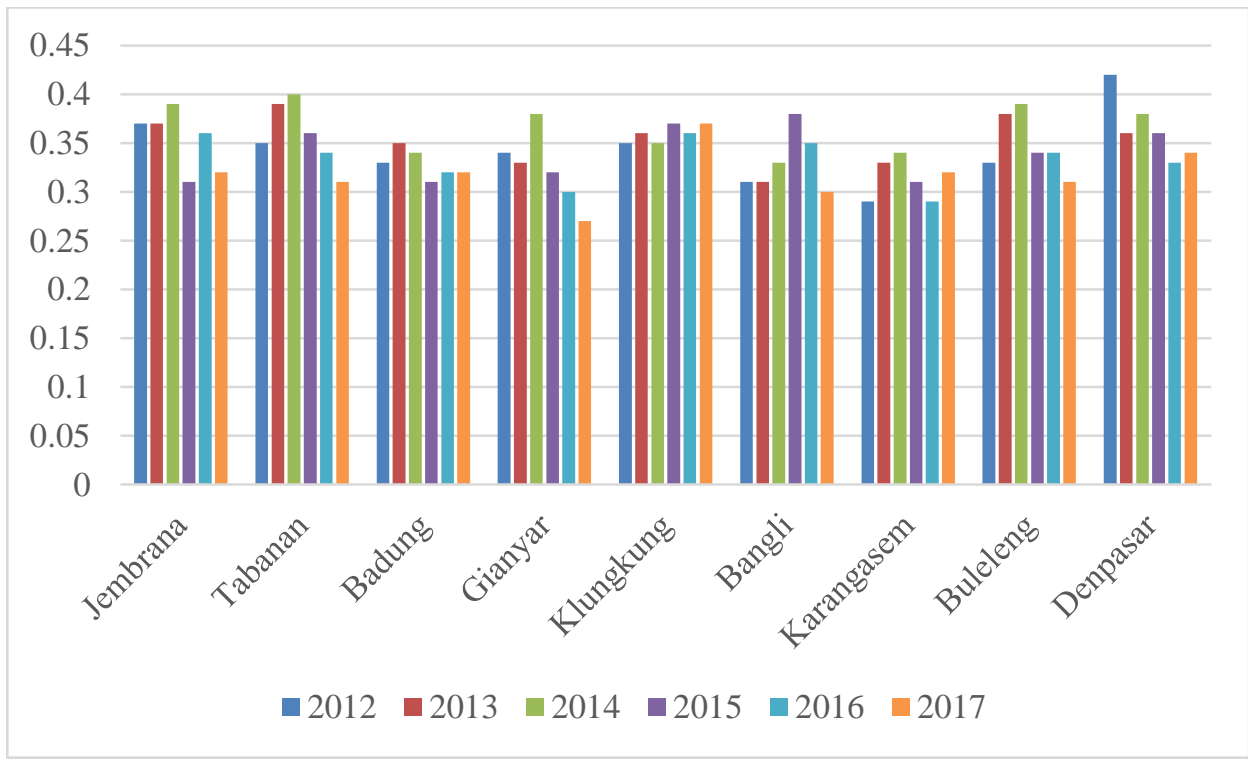

Figure1. Gini Coefficient Based on City/Regencies in Bali 2012-2017

Based on Figure 1, in 2012 and 2016 Karangasem Regency showed low income inequality criteria compared to other city/regencies with a Gini coefficient of 0.29. Criteria for inequality are occurring in Tabanan Regency with the largest Gini coefficient among other city/regencies, namely in 2013 amounting to 0.39 and 2014 at 0.40 . In 2015, Bangli Regency showed a moderate imbalance with a Gini coefficient of 0.38, then in 2017 the Klungkung Regency had a moderate imbalance with a Gini coefficient of 0.37. The city of Denpasar which incidentally is the heart of Bali Province in 2012-2017, the average inequality occurred, except in 2016 and 2017 showed low inequality with the Gini coefficient values of 0.33 and 0.44 respectively.

\subsection{Estimation Model}

The regression model in this study refers to the [5] model with four independent variables namely local government expenditure (million rupiah), regional minimum wages (million rupiah), population (thousands of people) and the contribution of the tourism sector. The dependent variable is the Gini index (Gini ratio). The research model of applying panel data analysis to the factors that influence the inequality of income distribution in Bali in 2012-2017 will be estimated as follows:

$$
Y_{i t}=\beta_{0}+\beta_{1} \ln X_{1 i t}+\beta_{2} \ln X_{2 i t}+\beta_{3} \ln X_{3 i t}+\beta_{4} \ln X_{4 i t}+u_{i t}
$$

Where

$Y$ : income inequality between city/regencies (Gini Index)

$X_{1}$ : regional government expenditure (million rupiah)

$X_{2}$ : regional minimum wage (million rupiah)

$X_{3}$ : population (thousand people) 
International Journal of Advances in Scientific Research and Engineering (ijasre), Vol 5 (7), July-2019

$X_{4}$ : tourism sector contribution

$\beta_{0}$ : constants

$\beta_{1}, \beta_{2}, \beta_{3}, \beta_{4}:$ regression coefficients

$i:$ regencies/city $(1,2,3,4,5,6,7,8)$

$t:$ year (2012-2017)

$u_{i t}$ : error component at time $t$ and city/regencies $i$

The panel data estimation can be determined through three approaches, namely Common Effect Model, Fixed Effect Model, and Random Effect Model will be explained as follows.

\subsection{Panel Data Analysis}

The following will be determined model estimation in the study of income distribution inequality in Bali in 2012-2017. The estimated results of the Common Effect Model using Eviews software are shown in Table 2.

Table2. Common Effect Model

\begin{tabular}{|c|c|c|c|c|}
\hline Variable & Coefficient & Std. Error & t-Statistic & Prob. \\
\hline$C$ & 0.584564 & 0.145954 & 4.005112 & 0.0002 \\
\hline$X 1$ & -0.006811 & 0.004393 & -1.550284 & 0.1275 \\
\hline$X 2$ & -0.003427 & 0.005225 & -0.655960 & 0.5149 \\
\hline$X 3$ & 0.001162 & 0.013637 & 0.085242 & 0.9324 \\
\hline$X 4$ & -0.026209 & 0.017936 & -1.461298 & 0.1503 \\
\hline
\end{tabular}

Based on Table 2, the model for panel data is formed as follows:

$$
y_{i t}=0.584564-0.006811 \ln x_{1}-0.003427 \ln x_{2}+0.001162 \ln x_{3}-0.026209 x_{4}
$$

The independent variables $\mathrm{x}_{1}, \mathrm{x}_{2}, \mathrm{x}_{3}$, and $\mathrm{x}_{4}$ are not significant as indicated by the probability value of each variable exceeding the level of $5 \%$. Furthermore, the estimated results of the Fixed effect model are shown in Table 3.

Table3. Fixed Effect Model

\begin{tabular}{|c|c|c|c|c|}
\hline Variable & Coefficient & Std. Error & t-Statistic & Prob. \\
\hline$C$ & 1.097436 & 0.253515 & 4.328873 & 0.0001 \\
\hline$X 1$ & -0.007115 & 0.003847 & -1.849672 & 0.0716 \\
\hline$X 2$ & -0.007009 & 0.010096 & -0.694186 & 0.4915 \\
\hline$X 3$ & -0.088220 & 0.043739 & -2.016982 & 0.0503 \\
\hline$X 4$ & -0.020399 & 0.015569 & -1.310259 & 0.1974 \\
\hline
\end{tabular}

Based on Table 3, the model for panel data can be written as follows:

$$
y_{i t}=1.097436-0.007115 \ln x_{1}-0.007009 \ln x_{2}-0.088220 \ln x_{3}-0.020399 x_{1}
$$

The independent variables $\mathrm{x}_{1}, \mathrm{x}_{2}, \mathrm{x}_{3}$, and $\mathrm{x}_{4}$ are not significant as indicated by the probability value of each variable is greater than the level of 5\%. In Table 4 the results of the Random Effect Model will be shown.

Table4. Random Effect Model

\begin{tabular}{|c|c|c|c|c|}
\hline Variable & Coefficient & Std. Error & t-Statistic & Prob. \\
\hline$C$ & 0.672130 & 0.148434 & 4.528129 & 0.0000 \\
\hline$X 1$ & -0.007825 & 0.003780 & -2.070159 & 0.0437 \\
\hline$X 2$ & -0.002674 & 0.007362 & -0.363154 & 0.7181 \\
\hline$X 3$ & -0.010834 & 0.020626 & -0.525254 & 0.6018 \\
\hline$X 4$ & -0.027999 & 0.015001 & -1.866548 & 0.0680 \\
\hline
\end{tabular}

Based on Table 4, the model for panel data can be written as follows:

$$
y_{i t}=0.672130-0.007825 \ln x_{1}-0.002674 \ln x_{2}-0.010834 \ln x_{3}-0.027999 x_{1}
$$

The independent variables $\mathrm{x}_{2}, \mathrm{x}_{3}$, and $\mathrm{x}_{4}$ are not significant which determine the probability value $>0.05$, while $\mathrm{x}_{2}$ significantly affects the gini index while the value of Prob $0.0437<0.05$. 
International Journal of Advances in Scientific Research and Engineering (ijasre), Vol 5 (7), July-2019

\subsection{Selection of the Best Model}

To get the best model, several tests will be carried out, namely the Chow Test and the Hausmann Test.

\subsubsection{Chow Test}

Chow test is a statistical test to determine the best model between common effect or fixed effect by testing the hypothesis as follows:

H0: Common effect model

H1: Fixed effect model

Table 5. Chow Test

\begin{tabular}{|l|c|c|c|}
\hline \multicolumn{1}{|c|}{ Effects Test } & Statistic & d.f. & Prob. \\
\hline Cross-section F & 3.896194 & $(8,41)$ & 0.0017 \\
\hline Cross-section Chi-square & 30.534093 & 8 & 0.0002 \\
\hline
\end{tabular}

The selection of the best model from the chow test can be seen from the p-value obtained from eview software. If the p-value is smaller than 5\%, the best model is the fixed effect model. The Chow test is processed using Eviews software. From the results processed, the $\mathrm{p}$-value is 0.0002 . This number is smaller than the error rate of $5 \%$ so the conclusion is to reject $\mathrm{H} 0$, meaning that the right model to use is a fixed effect model. The next step is to determine the best model between the fixed effect model and the random effect model with the Hausmann test.

\subsubsection{Hausmann Test}

Hausmann test is used to find out a better model between a fixed effect model and a random effect model. The Hausmann test is carried out with the following hypothesis:

H0: Random effect model

H1: Fixed effect model

Table 6. Hausmann Test

\begin{tabular}{|l|c|c|c|}
\hline Test Summary & Chi-Sq. Statistic & Chi-Sq. d.f. & Prob. \\
\hline Cross-section random & 5.755405 & 4 & 0.2182 \\
\hline
\end{tabular}

Hausman Test Statistics follow Chi-Square statistics. If the Hausman test statistic value is greater than the error rate of 5\%, the conclusion is accepted $\mathrm{HO}$ and the right model is a random effect model. If the reverse value of the Hausman statistic is smaller than the error level of 5\%, then the right model is the fixed effect model. With eview software obtained the Hausman Test with Eviews output in table 5.5. The value of P-Value 0.2182 is more than 0.05 , so reject $\mathrm{H} 1$ which means the best method that must be used is the random effect rather than the fixed effect.

\subsubsection{Classical Assumptions}

It is not relevant to carry out the classical assumption test because the best model obtained in this study is the Random Effect Model. The random effects model is estimated using Generalized Least Squares (GLS). GLS technique is believed to overcome the time series autocorrelation and the correlation between observations (cross-section). The GLS method produces an estimator to fulfil the Best Linear Unbiased Estimation (BLUE) characteristic which is a treatment method to overcome violations of heteroscedasticity and autocorrelation assumptions [6].

\subsubsection{Significance Test}

The selection of the best model by conducting the chow test and the Hausman test concluded that the random effect model was the best model in this study. Furthermore, after selecting the random effect model, it will be continued by looking at which variables influence the inequality of income distribution in Bali.

\subsubsection{Simultaneous Test}

The F test is conducted to find out whether the independent variables are simultaneously significant in influencing the response variable. 
International Journal of Advances in Scientific Research and Engineering (ijasre), Vol 5 (7), July-2019

Based on Table 7, the calculated $\mathrm{F}$ value is 2.626683 with $\mathrm{F}$ probability of 0.04 . The probability value $\mathrm{F}$ is smaller than the error level of $5 \%$. It can be concluded that together with the variables of regional government expenditure, regional minimum wages, population, and the contribution of the tourism sector influence the inequality of income distribution in this case seen from the Gini Index.

Table 7. Simultaneous Test of Data Panel

\begin{tabular}{|c|c|c|c|c|}
\hline Variable & Coefficient & Std. Error & t-Statistic & Prob. \\
\hline$C$ & 0.672130 & 0.148434 & 4.528129 & 0.0000 \\
\hline$X 1$ & -0.007825 & 0.003780 & -2.070159 & 0.0437 \\
\hline$X 2$ & -0.002674 & 0.007362 & -0.363154 & 0.7181 \\
\hline$X 3$ & -0.010834 & 0.020626 & -0.525254 & 0.6018 \\
\hline$X 4$ & -0.027999 & 0.015001 & -1.866548 & 0.0680 \\
\hline \multicolumn{5}{|l|}{ Effects Specification } \\
\hline & & & S.D. & Rho \\
\hline \multicolumn{3}{|c|}{ Cross-section random } & 0.022173 & 0.4371 \\
\hline \multicolumn{3}{|c|}{ Idiosyncratic random } & 0.025165 & 0.5629 \\
\hline \multicolumn{5}{|l|}{ Weighted Statistics } \\
\hline$R$-squared & $: 0.576564$ & \multicolumn{2}{|c|}{ Mean dependent var } & $: 0.143869$ \\
\hline Adjusted R-squared & $: 0.509344$ & \multicolumn{2}{|c|}{ S.D. dependent var } & $: 0.026902$ \\
\hline S.E. of regression & $: 0.025389$ & \multicolumn{2}{|c|}{ Sum squared resid } & $: 0.031585$ \\
\hline$F$-statistic & $: 2.626683$ & \multirow{2}{*}{\multicolumn{2}{|c|}{ Durbin-Watson stat }} & $: 1.651592$ \\
\hline Prob(F-statistic) & $: 0.045637$ & & & \\
\hline \multicolumn{5}{|l|}{ Unweighted Statistics } \\
\hline$R$-squared & $: 0.502564$ & \multicolumn{2}{|c|}{ Mean dependent var } & $: 0.342222$ \\
\hline Sum squared resid & $: 0.546786$ & \multicolumn{2}{|c|}{ Durbin-Watson stat } & $: 1.114967$ \\
\hline
\end{tabular}

\subsubsection{Partial Test}

The t-test is done to see how far individual independent variables affect the response variable.

\section{a. Effect of Regional Government Expenditures on Inequality in Income Distribution}

Based on Table 7 it can be seen that the variable coefficient of Regional Government Expenditure (X1) is -0.007825 with a probability of 0.0437 . The probability value of 0.0437 is smaller than the error rate of 5\%, this means that Regional Government Expenditures have a negative and significant effect on the inequality of income distribution. This shows that if a $1 \%$ increase in Regional Government Expenditures will cause a decrease in income distribution inequality by $0.7 \%$.

\section{b. Effect of Regency Minimum Wages on Inequality in Income Distribution}

Based on Table 7 it can be seen that the Regency Minimum Wage variable (X2) is -0.002674 with a probability of 0.7181 . The probability value of 0.7181 is greater than the error rate of 5\%, this means that the Regency Minimum Wage has no significant effect on the inequality of income distribution.

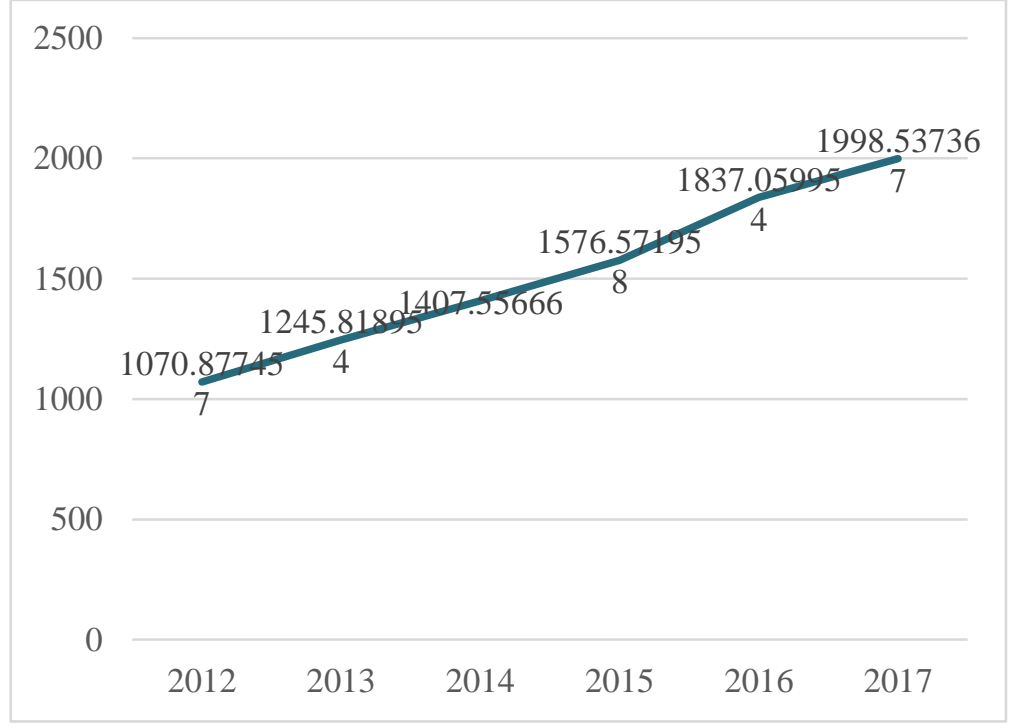

Figure 2. Regional Expenditures in Bali 


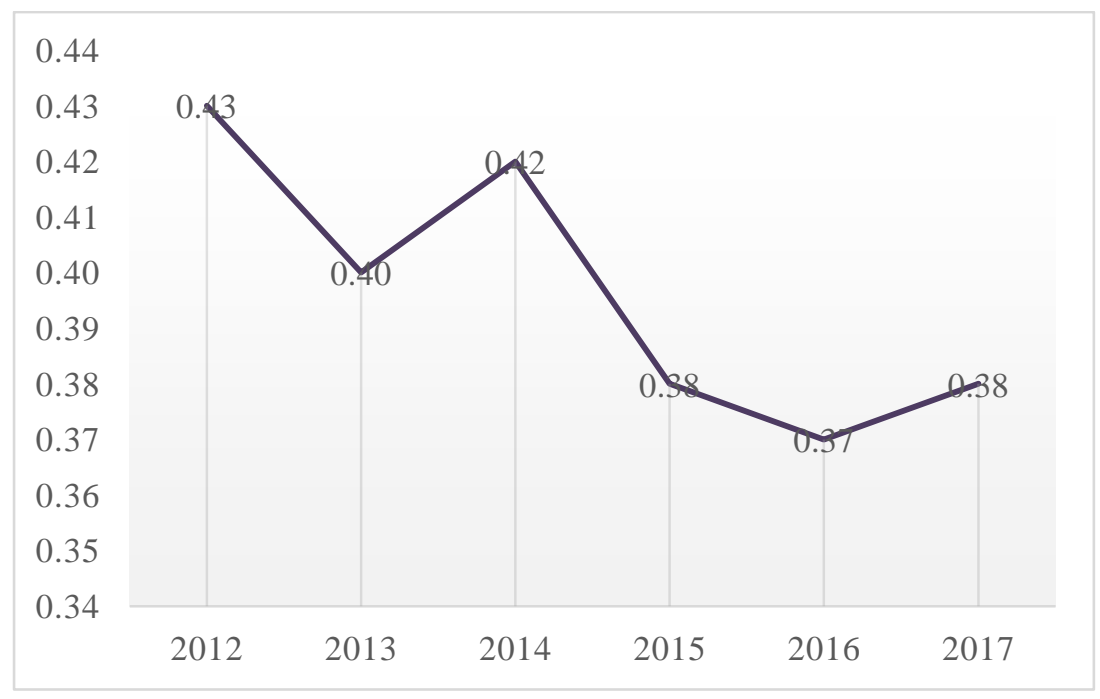

Figure 3. Bali’s Gini Coefficient.

Figure 2 shows that Regional Expenditures in Bali experience an upward trend where the largest regional expenditure growth rate is $16.52 \%$ in 2016. The Gini index shown in Figure 3 tends to decrease. The decline in the Gini Index is inversely proportional to the Regional Expenditure figures. High regional expenditure can encourage economic growth. Absorption of the Regional Revenue and Expenditure Budget will increase along with the high regional expenditure. Increased regional spending can encourage infrastructure, thus absorbing more labour. With increasing economic growth it will affect income inequality.

\section{c. Influence of Population Population on Inequality of Income Distribution}

The Population variable coefficient (X3) is -0.010834 with a probability of 0.6018 . The probability value of 0.6018 is greater than the error rate of 5\%, this means that the Population Population does not significantly influence the inequality of income distribution.

\section{d. Effect of Tourism Sector Contributions on Inequality in Income Distribution}

Based on Table 5.6 it can be seen that the variable coefficient of the Tourism Sector Contribution (X4) is -0.027999 with a probability of 0.0680 . The probability value of 0.0680 is greater than the level of error of $5 \%$, this means that the Contribution of the Tourism Sector has no significant effect on the inequality of income distribution.

\section{CONCLUSION}

In 2017, Klungkung Regency experienced a moderate imbalance with a Gini coefficient of 0.37 . The city of Denpasar which incidentally is the heart of Bali Province in 2012-2017, the average inequality occurred, except in 2016 and 2017 showed low bias with the Gini coefficient values of 0.33 and 0.44 respectively.

\section{SUGGESTIONS}

Furthermore, further analysis can be carried out on the influence of population, city minimum wages, regional expenditures, and the contribution of the tourism sector to income inequality in Bali Province in 2012-2017.

\section{ACKNOWLEDGMENT}

This research was supported by STIKOM BALI Institute of Technology and Business. We thank God and friends who provided insight and expertise that greatly assisted the research.

\section{REFERENCES}

[1] S. R. Chakravarty, "Equity and Efficiency as Components of a Social Welfare Function," Int. J. Econ. Theory, vol. 5, no. 2, pp. 181-199, 2009. 
[2] N. F. Wahiba and M. El Weriemmi, "The Relationship Between Economic Growth and Income Inequality,” Int. J. Econ. Financ. Issues, vol. 4, no. 1, pp. 135-143, 2014.

[3] A. M. Islam, "Economic Factors Affecting Distribution of Income Among Nations : A Preliminary Discussion," Hawaii Univ. Int. Conf. Arts, Humanit. Soc. Sci., 2014.

[4] BPS, Bali dalam Angka 2017. Badan Pusat Statistika Propinsi Bali, 2018.

[5] N. Akai and M. Sakata, "Fiscal Decentralization, Commitment and Regional Inequality : Evidence from State-Level Cross-Sectional Data for the United States," J. Income Distrib., vol. 18, no. 1, pp. 113-129, 2009.

[6] W. H. Greene, Econometric Analysis, Seventh Ed. Prentice Hall, 2012.

[7] Hadi Sasana, "Peran Desentralisasi Fiskal Terhadap Kinerja Ekonomi Di Kabupaten/Kota Provinsi Jawa Tengah,” J. Ekon. Pembang., vol. 10, no. 1, pp. 103-124, 2009.

[8] D. N. Gujarati, Basic Econometrics, Fourth Edition. United States Military Academy, West Point, 2004.

[9] L. F. Apriesa, "PERTUMBUHAN EKONOMI DAERAH DAN KETIMPANGAN PENDAPATAN ( STUDI KASUS : KABUPATEN / KOTA DI JAWA TENGAH ),” DIPONEGORO J. Econ., vol. 2, no. 1, pp. 1-12, 2013. 